\title{
THE ROLE OF THE HOME VISITING NURSE IN THE TOTAL EDUCATION PROGRAMME OF SPINAL CORD INJURED PERSONS
}

\author{
By N. I. E. BeER, S.R.N. \\ Royal Perth (Rehabilitation) Hospital, Shenton Park, Western Australia.
}

Summary. The provision of a Home Visiting Nursing Service, as part of the total rehabilitation team, plays an important part in preventing re-admission to hospital of spinal cord injured patients suffering from urinary tract infections or pressure sores. The Home Visiting Nurse provides discharged patients with a reinforcement of the educational aims of the rehabilitation programme, leading to greater success in their re-introduction both emotionally and physically leading to independent living.

Key words: Spinal cord injury; Home Visiting Nurse's role.

\section{Introduction}

WESTERN AUSTRALIA has a population of I.3 million people who enjoy a high standard of living, an increasing vehicle-to-population ratio and a warm, sunny climate, all factors which lead to many accidents resulting in spinal cord injuries. Motor vehicle accidents account for 75 per cent of all injuries, whilst swimming and diving accidents account for many of the remainder.

This large state of 2.5 million square kilometres is completely and adequately served by one Spinal Unit established in 1954 at Royal Perth (Rehabilitation) Hospital. The major philosophy of this unit is to educate and restore each individual to the fullest potential of independence.

\section{Home Visiting Service}

One facet of this programme is the Home Visiting Service which was set up in 1969 and has proved to be an important part of a successful team effort. Many re-admissions are prevented by the nurse constantly reinforcing all patient and relative education programmes which are taught during the acute and rehabilitation stages. This educational reinforcement, together with regular follow-up care, has helped the Home Visiting Service to:

I. Achieve its primary aim of a preventative nursing role.

2. Reduce the number of re-admissions to the Spinal Unit.

3. Help maintain social and domestic stability as well as achieving independence for patients which must always be the goal.

After a spinal injury not only is the patient's lifestyle completely and permanently changed but also that of the immediate family; therefore much preparation is needed by both patient and family to cope with this new situation.

The organisation in Perth has the Home Visiting Nurse as an integral 
part of the overall group who are responsible for education soon after the patient's admission. This early contact helps to build up a good rapport between the Home Visiting Nurse and the patient.

Prior to the patient's discharge from hospital the Home Visiting Nurse visits the immediate family to discuss with them the expectations they may have of special needs and capabilities. This visit is an important time for re-teaching and reinforcing any aspect of the education programme that may not have been fully understood. It is known that grief reactions vary greatly among different people, and so does emotional readiness to accept and learn at the time of attending the educational programme scheduled at the hospital soon after injury. Some people are hesitant to ask questions in group situations but feel less inhibited in their own homes. Although there are many important goals to be achieved throughout the course of medical rehabilitation, the main aim of patients is to eventually be able to return home.

By far the majority do return to their own homes. In Western Australia approximately 760 ( 89 per cent) reside at home, whilst 93 (I I per cent) are resident at the Quadriplegic Centre, which is a total nursing care hostel, separate from but adjacent to the Spinal Unit and managed by the Paraplegic-Quadriplegic Association of Western Australia Inc.

Modifications to homes of all spinal cord injured persons involves the Home Visiting Nurse. The state government of Western Australia, since I975, has subsidised alterations up to the sum of $\mathrm{A} \$ 3,000$. This is usually adequate to provide wheelchair access to the home, with suitable toilet and bathroom facilities. By-so doing, the government has acknowledged the need of each patient and incidently has found it to be very cost-effective.

\section{The role of the Home Visiting Service following discharge}

Once the home is adequately modified and all criteria and goals have been reached, including several weekends at home, the patient is then discharged. However, despite months of therapy and the efforts of many individuals, he/she often finds that the transition from hospital to home is fraught with unexpected obstacles and many problems not previously encountered or considered.

Within the first few days of their home-coming the nurse visits to help with the re-introduction to home life, giving emotional support. Both self-esteem and body image are low at this stage, and if these do not improve within a short time, the Home Visiting Nurse discusses the problem with the consultant from the Spinal Unit and, after consultation with the patient, may recommend psychological counselling (Beer, I98I).

On the practical side it may be necessary to implement further physical help such as district home nursing services, home cleaning services or (if living alone), the patient may require 'Meals on Wheels' provided by the local government body for a small charge.

When dealing with the care and long term follow-up of spinal cord injured nearly always the emphasis is on the physical care and so often the emotional side is neglected.

By listening closely to what each person has to say, by caring and by treating each problem individually, it is hoped to increase the quality of life not only physically but also emotionally. To quote Rudyard Kipling, 
'Words are, of course, the most powerful drug used by mankind'.

Physical problems such as recurring pressure sores are usually a manifestation of either social or financial factors, or even a plea for more attention from one's family. These signs should be quickly recognised by the Home Visiting Nurse and the patient directed to the appropriate specialist.

The success of the education and the nursing programme at Royal Perth (Rehabilitation) Hospital is exemplified by the declining rate of re-admissions to hospital of patients with pressure sores and/or urinary tract infections. There was a 34 per cent decrease in the incidence of admissions for pressure sore treatment from the years $197 \mathrm{I}-73$ to the period $1977-79$ and bed occupancy per year for their treatment decreased by 30 per cent over the same period (Silvester et al. I980).

Table I shows that heels and malleoli are the most commonly affected areas seen by the Home Visiting Nurse, and this is reflected in Table II where it is seen that these areas represent the least commonly admitted causes. Such cases are more successfully being treated at home, leaving a higher proportion of longer term pressure areas such as ischial, sacral and greater trochanteric areas in hospital. This is shown by the increase in average treatment time over the period mentioned of 16 per cent (Noble I98I).

\section{TABLE I}

Pressure areas cases successfully treated at home by home visiting service $1978-82$

\begin{tabular}{lclc}
\hline Site & Number & Site & Number \\
\hline Heels & 52 & Trochanters & 22 \\
Malleoli & 46 & Tibia & I8 \\
Ischium & 44 & Knees & 13 \\
Sacrum & 39 & Elbows & I0 \\
Toes & 25 & Spinous Process & 6 \\
& & Pubic/perineal & 5 \\
\hline
\end{tabular}

\section{TABLE II}

Relative severity of pressure sores admitted to hospital in terms of duration of treatment and the anatomical site of the sore

\begin{tabular}{|c|c|c|c|c|}
\hline $\begin{array}{l}\text { Anatomical } \\
\text { Site }\end{array}$ & $\begin{array}{l}\text { Proportion of } \\
\text { all Pressure } \\
\text { sores }\end{array}$ & $\begin{array}{c}\text { Mean } \\
\text { Treatment } \\
\text { Time (Days) }\end{array}$ & $\begin{array}{l}\text { Relative } \\
\text { Treatment } \\
\text { Time }(62 \cdot 6 \\
\text { days }=\mathrm{I} \cdot 00)\end{array}$ & $\begin{array}{l}\text { Proportion of } \\
\text { Treatment } \\
\text { time for all } \\
\text { Pressure sores }\end{array}$ \\
\hline $\begin{array}{l}\text { Ischial } \\
\text { tuberosities } \\
\text { Greater }\end{array}$ & $3 \mathrm{I} \cdot 2 \%$ & $73 \cdot 8$ & $\mathbf{I} \cdot \mathbf{I} 8$ & $36 \cdot 8 \%$ \\
\hline $\begin{array}{l}\text { Trochanters } \\
\text { Sacrum } \\
\text { Lateral malleoli } \\
\text { Heels }\end{array}$ & $\begin{array}{r}9 \cdot 7 \% \\
16 \cdot 2 \% \\
10 \cdot 0 \% \\
10.7 \%\end{array}$ & $\begin{array}{l}\text { I } 27 \\
79 \cdot 4 \\
37 \cdot 3 \\
39 \cdot 1\end{array}$ & $\begin{array}{l}2 \cdot 03 \\
1 \cdot 27 \\
0 \cdot 60 \\
0 \cdot 62\end{array}$ & $\begin{array}{r}19 \cdot 7 \% \\
20.5 \% \\
6.0 \% \\
6 \cdot 7 \%\end{array}$ \\
\hline
\end{tabular}


It is emphasised that all pressure sores treated at home heal without the use of antibiotics, either systemically or topically, and usually do so without any signs of infection such as cellulitis or inflammatory oedema. Advice given to patients is 'You can put anything on a pressure sore except your weight'. An appointment following the healing of a sacral or ischial pressure sore is routinely made with the Pressure Clinic to check whether the wheelchair or cushion are contributing factors. All wheelchairs in Western Australia are now individually prescribed and manufactured to the specific need of the user to maintain the best possible posture and to prevent undue pressure or friction on any given area.

Another most important area in the role of the Home Visiting Nurse is the education towards the prevention, early detection and treatment of urinary tract infections. When an infection is suspected the nurse is contacted, a sterile midstream urine sample is collected and, after microbiology and culture, treated if needed with the appropriate antibiotic.

When urinary tract infections become recurrent an appointment is made with the Urology Clinic for investigation, such as residual urine, cystometry and intravenous pyelogram, to exclude any mechanical dysfunction. If no obstructive factor for repeated infections can be found the nurse then investigates further possible sources of infection in the home. Education on meticulous personal hygiene must be emphasised, together with the care of equipment and facilities. Cracked or loose tiling provides a ready medium for the growth of gram negative bacteria and these have been detected and cultured occasionally.

It may be necessary to take swabs for culture from specific areas in the home working in close liaison with the microbiologist, who then gives advice and suggests treatment for the eradication of such infections. Usually with diligence, co-operation and information on the reasons why urinary tract infections occur, most recurrent cases can be eradicated. This is illustrated by the small number of patients admitted to hospital each year by the Home Visiting Nurse for the treatment of urinary tract infections (Table III).

TABLE III

Patients seen at home requiring hospitalisation for urinary tract infections

\begin{tabular}{lcccc}
\hline Year: & 1976 & 1978 & 1980 & 1982 \\
Patients: & 8 & 2 & 6 & 3 \\
\hline
\end{tabular}

Direct contact by telephone between patient and nurse is routine each working morning and is an essential part of the philosophy that 'early intervention prevents later complications'.

\section{Conclusion and Evaluation}

The efficiency and success of the Home Visiting Service relies upon the direct contact maintained between the nurses and the consultant doctors of the Spinal Unit. This allows for immediate re-admission to the Spinal Unit for any patients encountering problems that cannot be managed in the home. 
The value of the service has become clear and benefits have been seen in two major areas. Economically, by keeping the re-admission rate low expense of providing costly medical care is minimised. Secondly, the present Spinal Unit building at Royal Perth (Rehabilitation) Hospital is a facility which opened in 1963 with 40 beds to service a state population of 808,443 ; yet it is still adequately servicing a population of $1,342,000$ in 1983 without having to increase bed numbers. In fact, an average of 30 beds is now regularly used. Had bed requirements risen at the same rate as the population increase, then an extra 25 beds would have been needed in 1983 . This represents a cost saving of $\mathrm{A} \$ 1.55$ million.

To maintain this as a preventative and educational service, an increase in the number of Home Visiting Nurses to keep the nurse/patient ratio within practical bounds will be needed. Any increase in cost that this will entail will be more than offset by the considerable savings made by forestalling preventable hospitalisation.

In conclusion, the operation of the Home Visiting Service, working in conjunction with the Outpatient Department and the total rehabilitation team, can be seen as a necessary factor in re-inforcing patient, relative and community education, and in the after-care and long term management of spinal cord injuries.

\section{RÉSUMÉ}

Les visites à domiciles par des infirmières représentent une grande partie des services généaux des réhabilitation pour les patients souffrants des infections du système urinaire et/or des endroits douloureux par suites des maladies de la moelle épinière. Ces visites contribuent à éviter un autre séjour à l'hospital. En plus, les soins que donne une infirmière à un malade dans son foyer propre sont indispensables à faciliter sa rentrée dans une vie normale et indépendante.

\section{ZUSAMMENFASSUNG}

Heimbesuche durch Pflegepersonal als Teil der Wiedereingliederungs-Hilfe spielen eine grosse Rolle bei Patienten, die als Folge von Rückenmarksverletzungen an Blaseninfektionen und/oder Druckschmerzen leiden. Eine Wiedereinlieferung ins Krankenhaus kann dadurch oft vermieden werden. Die Hausbesuche einer Krankenschwester bilden auch eine ausgezeichnete Hilfe für den Patienten, der psychisch und praktisch zu einer unabhängigen Lebensweise zurückfinden will.

\section{REFERENCES}

BEER, N. I. (198I). Domiciliary Visiting in Western Australia. Australian Nurses fournal, I0, 40-4I.

Noble, P. C. (1981). The Prevention of Pressure Sores in Persons with Spinal Cord Injuries, pp. 5-45 World Rehabilitation Fund Inc. New York.

Silvester, W. and Sallie, R. (1980). A Study of the Reasons for Re-admissions of J'pinal Injury Patients to the Royal Perth (Rehabilitation) Hospital Spinal Unit. Department of Medicine, University of Western Australia, pp. 8-9. 